\title{
Gestalt Theory and Gestalt Principles in Religious Structures
}

\author{
Reyhan (Gedikli) Akat ${ }^{1}$, Birgül Çakıroğlu²
}

\author{
${ }^{1}$ Dr., Ministry of Environment and Urban Planning, Presidency for Strategy Development, Ankara, Turkey \\ ${ }^{2}$ Dr., Department of Construction and Technical Works, Karadeniz Technical University, 61080, Trabzon, Turkey
}

\begin{abstract}
In this study, basic design concepts related to Gestalt principles were examined. In the first phase of the work, the principles that Gestalt theory developed in the field of visual perception are introduced and the basic design principles are explained by various abstract examples. In the second phase, gestalt principles have been tested with concrete examples of the various existing implementations. As a study area; In Turkey, various examples of religious architectural buildings were selected. These types of structures; Early and classical mosque, medrese and tomb examples. As a result of the analysis of the religious architecture samples taken into consideration; The types of structures are expressed in basic design principles, which are related to guttal theory. After all; The importance of implementing design concepts related to gestalt principles in the construction has been emphasized.
\end{abstract}

Keywords: Gestalt Principles, Basic Design Concepts, Religious Structure

\section{INTRODUCTION}

In America, a group of German psychologists were conducting important research on the human perception system and process in the wake of behaviorism. Max Wertheimer [1880-1967], Wolfgang Köhler [1887-1967] and Kurt Koffka [1886-1941] did not share the views of structuralism and behavioral approaches. These psychologists; They divided the psychological processes and opposed the way of judging the whole. I mean, according to them; The whole is bigger than the pieces that bring it to the square. In German, the Gestalt word is used as a whole, in the sense of completeness, a certain form or pattern [Özbay, 1999]. In other words; Biological, or psychological structure, sequence, or pattern that includes a functional integrity that can not be obtained from the sum of its parts.

The experimental work of Köhler [1929], which explains the relation between mental schemes and environmental order, laid the foundations for Gestalt Theories of Perception. According to this, the objects that make up the environment are gathered together in a certain order and the perception is explained by the mental schemes formed by the elements of this order. The simplest, but most fundamental, principle of perceptual regulation is that the forms perceived as 'form against the floor' have visual activity; The shape is the shape-ground relation defined by the expression 'the meaning of the background forming the back surface'. The figure-to-ground relation, with reversible concepts, gives them meaning to be perceived within a certain order of randomly assembled items. The original focus of the Gestalt theory is not behavior, but human perception and other knowledge processes. It is a theory that is very interested in visual perception. The main concept of the theory is the 'Gestalt' form-figure concept. The form is defined as 'any piece of whole or whole separated [Graves, 1951; Gürer, 1990].

Gestaltians have drawn attention to the whole of the spiritual events and to the organization. According to them, experiences are all complex and complex. These are physical, environmental and intrinsic, the fact that many factors are organized in certain forms. So all that is formed is something more than the sum of the inward ones, and it has its own particular qualities. For example, Helson and Fehrer; They have reached various definitions of Gestalt.

These;

- The shape of a perceived whole

- Some factors within a dominant group

- Sum of defined conditions of a spouse, moment or behavior model

- Physical structures

- Biological structures

- Logical structures

- Psychological structures

- Objectives

This article is published under the terms of the Creative Commons Attribution License 4.0 Author(s) retain the copyright of this article. Publication rights with Alkhaer Publications. Published at: http://www.ijsciences.com/pub/issue/2017-08/

DOI: 10.18483/ijSci.1402; Online ISSN: 2305-3925; Print ISSN: 2410-4477 
- It can be listed as necessary and sufficient conditions [Graves, 1951; Gürer, 1990].

The Classification Regarding Gestalt Principles is as follows;

- The most important feature that an edit from some angles can have is the format.

- Visual forms are dynamic or outgoing dynamic processes behind them.

- The first and simplest arrangements are the attributes on the ground. All visual forms have at least two separable sides, a shaped part and a background called the background.

- Visual forms have one or more center of gravity organized by the form. The effect of the center of gravity on shape is important.

- Visual forms can be transformed into another point, another region, another orientation, another point on the visual field without losing their identity.

- Visual forms tend to resist change, preserving their structure against destructive forces.

- Forms are good at the extent allowed by the dominant conditions.

- Visual forms can be combined to produce innovations. Simple forms are easier to join than complex ones, those of the same power are easier than those of different powers.

- Affects other parts and sides of a form of change on one side of the visual form. Changing part of the visual form changes the whole form. The better the form, the stronger the effect.

- Visual forms tend to appear and disappear as a whole.

- Visual forms leave behind effects that make it easier for them to keep their minds in relation to unformed entities. A part of a form that has been seen in its entirety before, tends to remind the whole form when it is seen as a part of the form again. Phenomenal spaces are not 'isotropic', they carry different characteristics in different directions [Graves, 1951; Gürer, 1990; Aydınl,, 1993].

\subsection{Gestalt theory of visual form}

Gestalt theory has influenced the feelings and ideas of architects, artists, and environmental designers in recent years; It also sheds light on aesthetic perception problems that are part of ecological approaches that explain how perception is perceived. According to Gestalt's theory, it is not the parts that make sense of a whole, How these pieces come together and the relationship between the pieces. In order to understand this relation, it is necessary to briefly look at the concepts of form, isomorphism and field forces. The form is a basic concept that is a stand-alone activity as a closed and fiction-based element in the visual world; It is perceived by the effect of its shape, which is integrated with it, but which is self-evident, without interrupting the homogeneous effect of the back ground. In Gestalt theory, many principles have been developed that affect the perception of form: Proximity, similarity, good shape feature, closeness, continuity, continuity, encirclement, symmetry, etc. .

\subsection{Perceptual organizational principles}

\subsubsection{Form-ground relationship principle}

Certain visual characteristics tend to be seen as spatial formations. They are white and black speckles of varying sizes as seen in Figure 1. But the eye immediately arranges and groups these visible differences. Some of the black speckles show a different shape while they are seen as one. Some elements are seen together because they are close to each other. Since others are similar in size, direction, and form, we will perceive the human figure similar to the picture after we make an instant arrangement. Here, the visual relationship of the visual field elements is the result of our mind's ability to organize, comprehend and shape the greatest spatial field in such a short period of time.
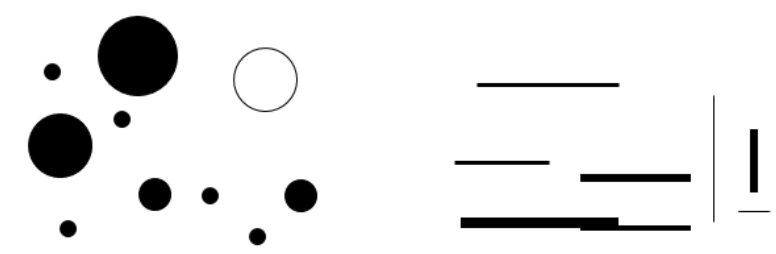

Figure 1. Form-ground relationship principle

\subsubsection{Proximity principle}

Proximity is the simplest of the organization. Objects close to each other tend to group together again. Depending on the Gestalt theory, relative closeness provides a strong tendency of interdependence among the sensory units. Forms that stay away from one another do not appear to be related to each other. They feel irrelevant and scattered. Proximity can be two-dimensional or three-dimensional. The spacing between these shapes should be adjusted to that amount so that you can feel that the shapes come together for the same purpose and that they are related to each other. When we hear the words, we understand them with the temporary closeness of the sounds. We are literally literate as separate entities. Because the words of a lamb are closer to each other than the letters at the end and the end of two separate lambs [Graves, 1951]. The closeness principle in the visual organization occurs under the simplest conditions: Relative proximity tends to group visually together items close to each other, since the sensory units exhibit little resistance in the interconnection. In Figure 2, lines and columns are arranged at even intervals, resulting in a superficial texture / pattern, while items close to each other reinforce the line effect. 


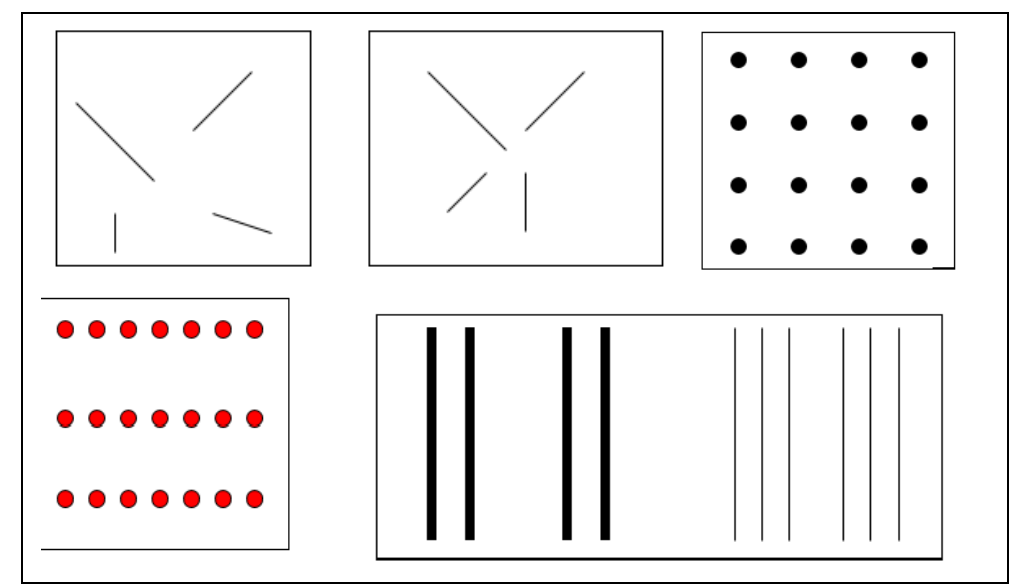

Figure 2. Proximity principle

\subsubsection{Similarity principle}

As in Figure 3, if items are of similar size, texture and color, they are perceived as a single unit; This is called the similarity principle. To facilitate the aesthetic experience, affinity and similarity principles help the form of field forces gain an effective appearance. If the forms in the field of view are completely different from each other, it is difficult to relate them. Such forms appear irrelevant and random. However, because of their similarity in shape, color and texture, it is tried to find a connection between them.
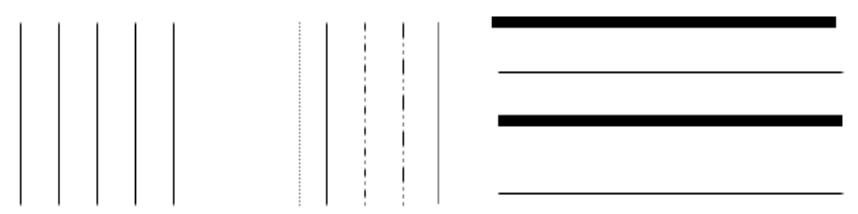

Figure 3. Similarity principle

\subsubsection{Good Shape Feature principle}

'Structures or shapes that have become different from the surrounding ground are' GOOD '. So, as clear as possible, effective and stable. The GOOD changes from situation to situation and includes some features. These; Simplicity, symmetry, order, unity, continuity, scope, etc. . When Humbell told his subjects to change patterns to make the mottled shapes as good as possible, the subjects tended to distinguish the structure in the way of increasing the original symmetry, simplicity and completeness [Graves, 1951]. As a result; A simple, symmetrical, neat, rhythmic arrangement has become more precise.

\subsubsection{Symmetry principle}

Generally, the effects of geometric and visual forms are more precise and easier to adopt. There is a stable balance between them. If a part of a form creates a symmetry axis effect, it is desired that it appear as the view of the former one on the other side. In addition, symmetry plays a positive, definitive and expeditious role in ensuring quality.

\subsubsection{Consolidation, continuity principle}

As a result of the experiments made, the parts which do not continue to form are joined together to give a full shape form and the lines are added. Completion and continuity tendency is provided by the blind spot, neglecting the void in the warning. Even if the person knows that the area is objectively absent, a closed form can be established from the absent parts [Graves, 1951]. In the law of closing, visual units tend to be tightly closed in shape by the power of the organization. In another way, almost completed forms tend to be whole. As a consequence of this, the closed form is more stable and continuous than the unsteady ones. Closure / completion and good continuity principles also explain that people tend to perceive items of continuity as a single whole. The figure in figure 4 is not two (L); As two intercepting lines; Figure 5 is perceived as a two-dimensional surface behind two planes.

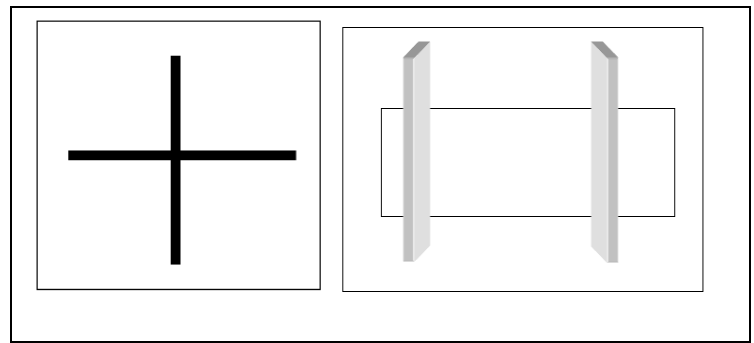

Figure 4. Consolidation, continuity principle

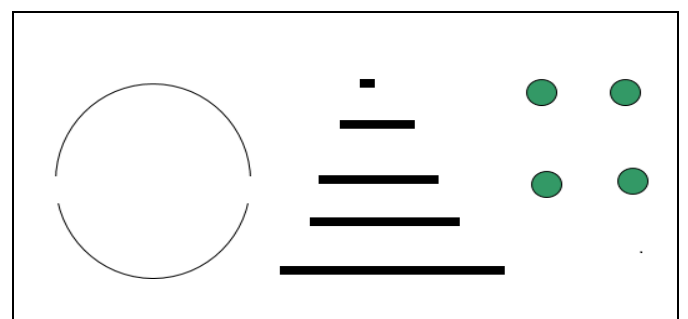

Figure 5. Consolidation, continuity principle 


\subsubsection{Experience factor principle}

It should also be borne in mind that previous experience will be effective from time to time. Whether it is two-dimensional or three-dimensional, if it is desired to emphasize the form in an arrangement more, 'shape narration' is applied. These;

- Depth,

- Linearity and,

- Effective environment.

Depth: If two-dimensional or three-dimensional side by side or a lot of shapes standing at a distance feel that we are at different distances, then these shapes can give depth expression (Figure 6). Depth;

- Coverings

- Transparency,

- Derminal grading,

- General dimensional grading,

- Is evaluated as a value grade.
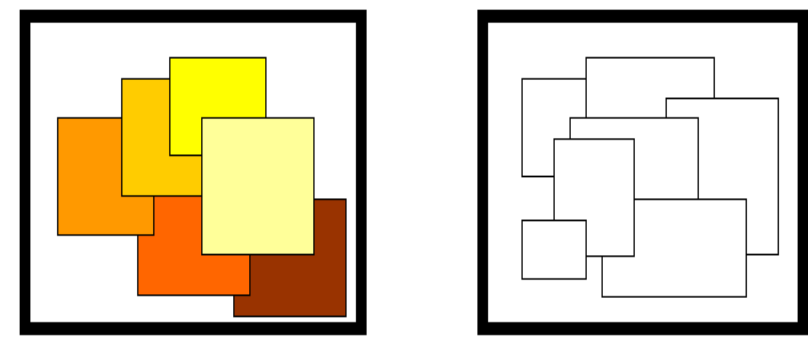

Figure 6. Depth

Linearity: This line of expression is called linearity, in which the lines draw the lines without losing their identity (Figure 7).

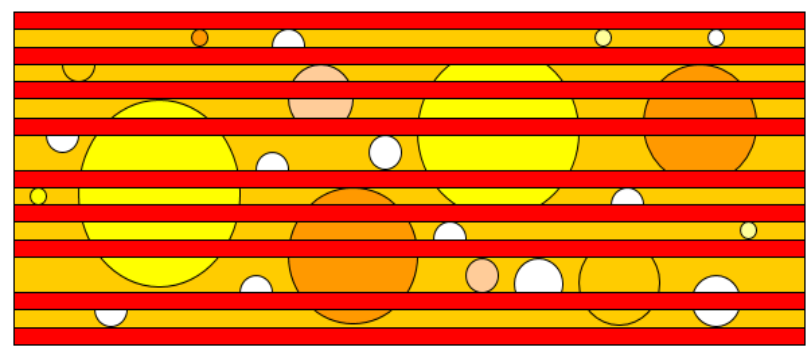

Figure 7. Linearity

Effective Environment: If the shape is not contour, if it is at the same brightness as the floor, it is soft and indistinct if the color is separate. If a contour is made around it, the shape appears to be effective and welldefined (Figure 8).
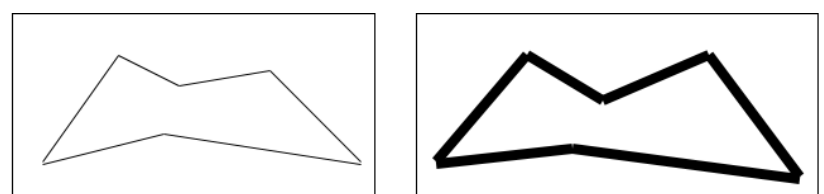

Figure 8. Effective Environment
All these above mentioned principles are explained with the aid of isomorphism. A hypothetical parallelism among the forms that result in perceptual experience as a result of scientific reasons underlying neurological processes explains the concept of isomorphism. According to Rudolf Arnheim [1965], the "feelings" experienced when looking at visual objects can be thought of as the psychological counterpart of the physiological forces that are active in the visual center of the brain. This process, which takes place physiologically in the brain, actually reflects the physical properties of the perceived objects. Just as field forces are in mathematics, it can be said that they have an application field, a direction and a gravitational force [Graves, 1951]. These forces are governed by the "PRAGNANZ PRIMARY". According to this principle, perception occurs in stable and stable form under different conditions.

\section{MATERIALS AND METHODS}

\subsection{Field of work - Sample selection}

Selected examples of study area; have been selected from among the types of religious architecture belonging to which they have reached to daylight, have not lost their characteristic, These types of structures; early and classical mosque, madrasa and tomb examples. For this study, Bursa, Edirne, Istanbul and İznik cities were selected in Turkey (Figure 9).

As a result of the analysis of the religious architecture samples taken into consideration; The types of structures are expressed in basic design principles, which are related to guttal theory.

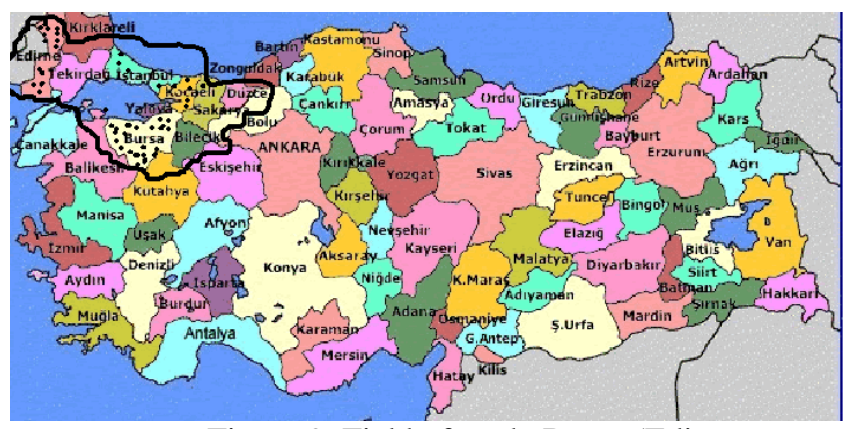

Figure 9. Field of study Bursa (Edirne, Istanbul and İznik cities-Turkey)

\subsection{Methods}

There is no standard category of design principles. These principles, which the researcher put forward, differ in terms of meaning and definition: the regulatory principles set forth by Ching; Axes, symmetry, hierarchy, rhythm, datum, we can reorder [Ching, 2002]. 
The principles laid out by Uraz indicate Ching as a source; Axis, axis, symmetry, hierarchy, rhythm, datum [Uraz, 1993].

Divanlığlu ranked axis, sovereignty, rhythm and repetition, conformity, contrast, koram, balance, unity [Divanlığlu, 1997].

Principles set forth by Gürer; Again, harmony, contrast (contrast), koram, sovereignty, balance and unity. The principles of design, the elements one by one among themselves; As well as in relation to the "whole". Another change; In the solution of a problem, in an arrangement, line, color, texture ... etc. Are helpful elements in using basic elements. Because each composition is a unified order of these basic elements at various ratios [Gürer, 1990].

In this work, the formal principles discussed are as follows.

1.Symmetry

2. Sovereignty

3. Rhythm (repeat) (repetition)

4. Balance

5. Contrast

6. Koram

7. Conformity (Harmony)

8. Union

\section{RESULTS}

3.1. Symmetry: requires a balanced and equivalent form and space to be arranged around, around a common line (axis) or point (center). Forms, shapes arranged in a glance are more noticeable and memorable than non-glazed ones [Divanlığlu, 1997]. Symmetrical elements tend to be easier to create Gestalt than similar elements [Gürer, 2004].

According to Vitruvius, symmetry is the link between all the different elements of the design, all according to the right harmony and criterion of an artifact between its elements [Vitruvius, 1993].

Divanlığlu basically defines two symmetries.

- Bilateral symmetry: The arrangement of equivalent items with a common axis.

- Radial symmetry: balanced arrangement of elements equivalent to two or more axes intersecting at the central point (Figure 10), [Divanlıoğlu, 1997].

Radial symmetry in nature usually results in a small number of factors. Natural shaping prefers dynamic grouping. The human being applies the whole or partial symmetry for a long time in compositions composed with many items. This tendency, seen in many major art ages, is the product of a rational worldview that favored the abstract organization of organic formation [Kuban,1989]. Bursa Orhan Bey Mosque shows symmetry in many examples such as Ahmet Pasha Mosque, Yeni Mosque, Nuruosmaniye Mosque, Kapıağası Madrasa, Yıldırım Madrasa and Çelebi Mehmet Madrasa plans in the twin arches of the last congregation, Şehzade Mosque courtyard front, Suleymaniye Mosque courtyard entrance, (Figure 11, Figure 12, Figure 13).

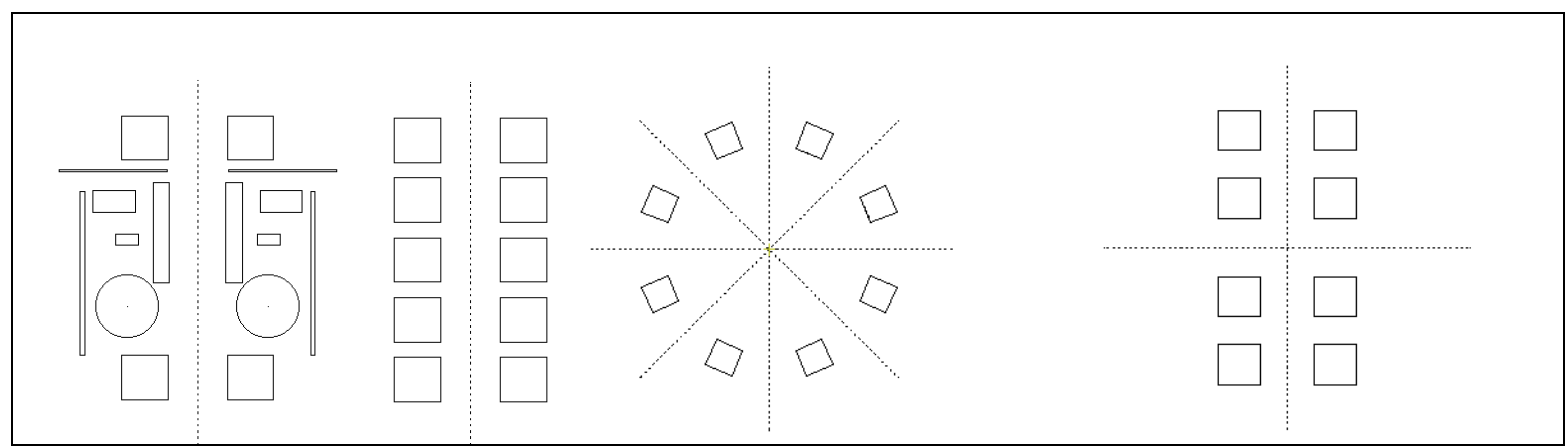

Figure 10. Bilateral symmetry, radial symmetry
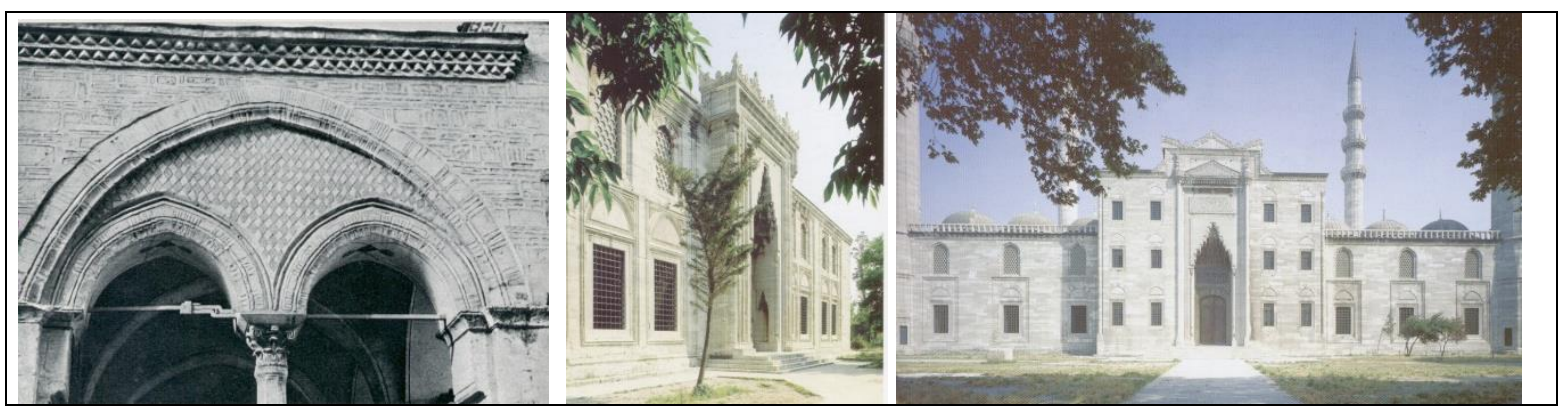

Figure 11. Orhan Bey Mosque (Bursa) [Aslanapa, 1977], Şehzade Mosque courtyard front facade (Istanbul) [Günay, 2002], Suleymaniye Mosque courtyard entrance front (Istanbul) [Günay, 2002] 


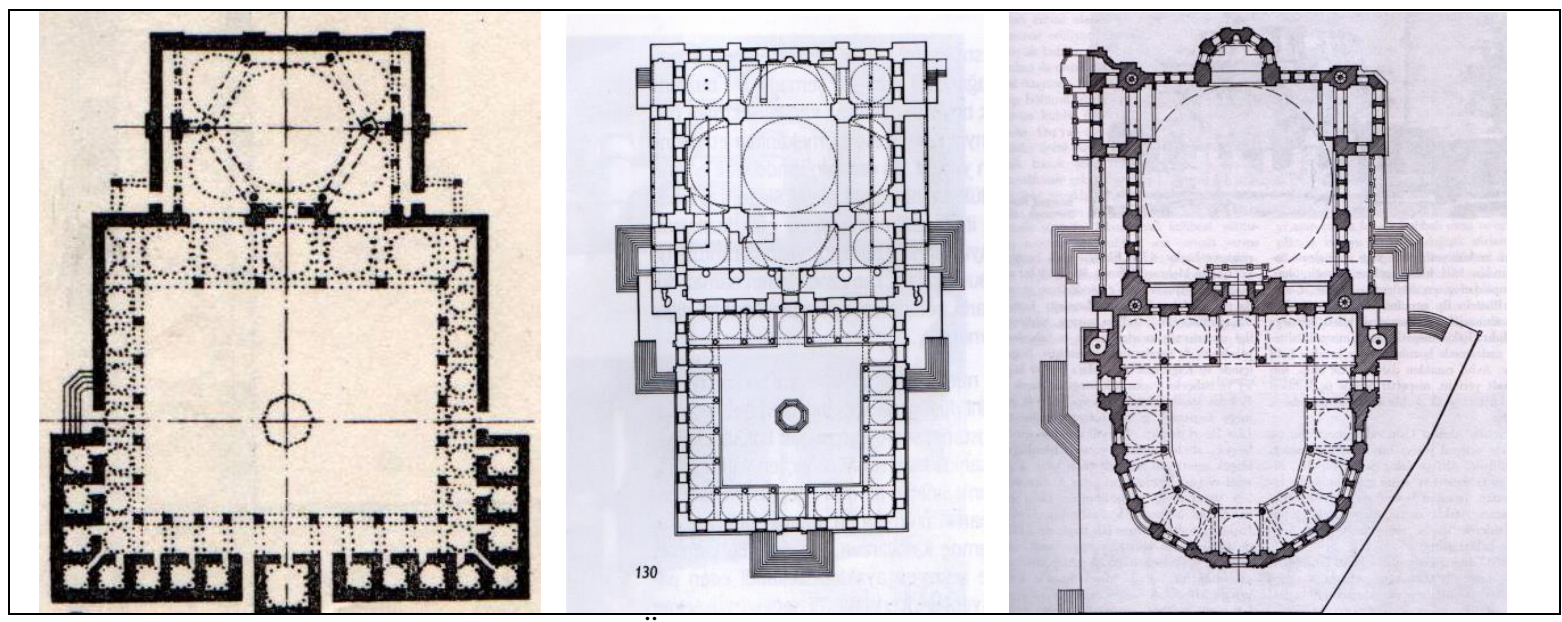

Figure 12. Ahmet Pasha Mosque (Istanbul) [Ünsal, 1959], Yeni Cami (Istanbul) [Kuban, 1998], Nuruosmaniye Mosque (Istanbul) [Aslanapa, 1993]

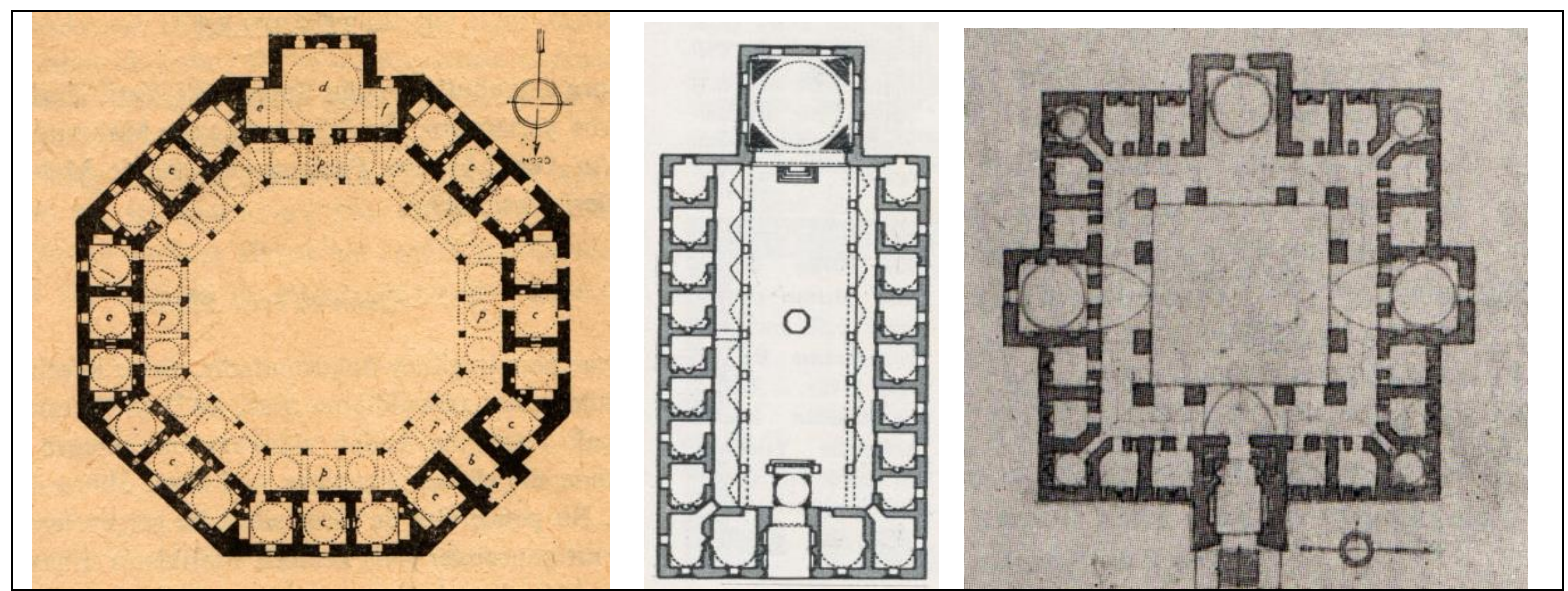

Figure 13. Kapıağası Madrasa (Amasya) [Yetkin, 1970], Yıldırım Madrasa (Bursa) [Aslanapa, 1977], Çelebi Mehmet Madrasa (Merzifon) [Ünsal, 1959]

3.2. Sovereignty: Sovereignty is when one of the items used in a vase, or one group, gives superiority to other items in terms of size, color, texture and similar care. All kinds of sovereignty are provided in opposition. These differences, in a sense, reflect the significance of these forms and spaces and their role in formal, formal, and symbolic play. In an architectural arrangement, a form or a space can be dominated by giving a different dimension (small to large) than all other items in the arrangement. Forms and spaces can be dominated visually from one form to the other by their apparently different form [Divanlıoğlu, 1997].

Sovereignty is an effective principle in balance and unity. They dominate the dominant element or group of elements and they have a strong influence. If there is a dominant element participating in the organization, it will make a difference and destroy the monotony, it will help the attention to that direction, so it will stimulate the excitement and attract attention. It can be said that the sovereignty is generally provided in the opposite direction. Sovereignty also helps to identify the building, space, or element that the designer is interested in, especially in architectural applications [Ustaömeroğlu, 1998].

Sovereignty comes to the forefront through the interplay of the transition and the opposition in the relational organization of forms. Sovereignty also forms the balance feature on the whole of forms [Gürer, 1990].

Sovereignty differs in terms of functional, formal, symbolic values in the regulation of architectural forms. Sovereignty measure, value, color, texture etc. Diversity of care. Among them is the rule of measure, which can be used and understood most [Güngör, 1983].

In order to be important in space, space and form, it has to be visible only. Within the organization, shape, measure and position differentiation can be created to make the spaces, buildings, building groups dominant. These features are created as follows:

- Special dimension (measure): In an architectural arrangement, a shape or a different 
dimension from all other elements participating in the arrangement of a space can be given a prefix and dominated to arrange it. Naturally, this sovereignty is visualized with different dimensions. In this layout the form can be small and large in size. If it is small, it can be dominated by the well-defined place [Tavşan, 2000, Ching, 2002]. Şehzade Mosque (Istanbul), Ahmet Pasha Mosque (Istanbul) as well as the dominant ögedir in form with the central dome's special dimension (Figure 14).

- Different form than the others: Form or space is formally differentiated from other elements in composition. They may dominate visually from the others to form with their distinctly different forms. This differentiation is possible by contrasting geometry patterns [Tavşan, 2000; Ching, 2002].

- Convenient, Strategic position: Form and space occupy a significant place in the composition with its strategic position besides other features. The scope of hierarchies or locations that are hierarchically important for shape and location can be counted as follows;

○ Limit of linear arrangement or axial arrangement

- The centerpiece of the conciliar arrangement

- It is classified as focal point of the central or radiative regulation (Figure 15) [Ching, 2002; Divanlıŏlu, 1997, Tavşan, 2000].
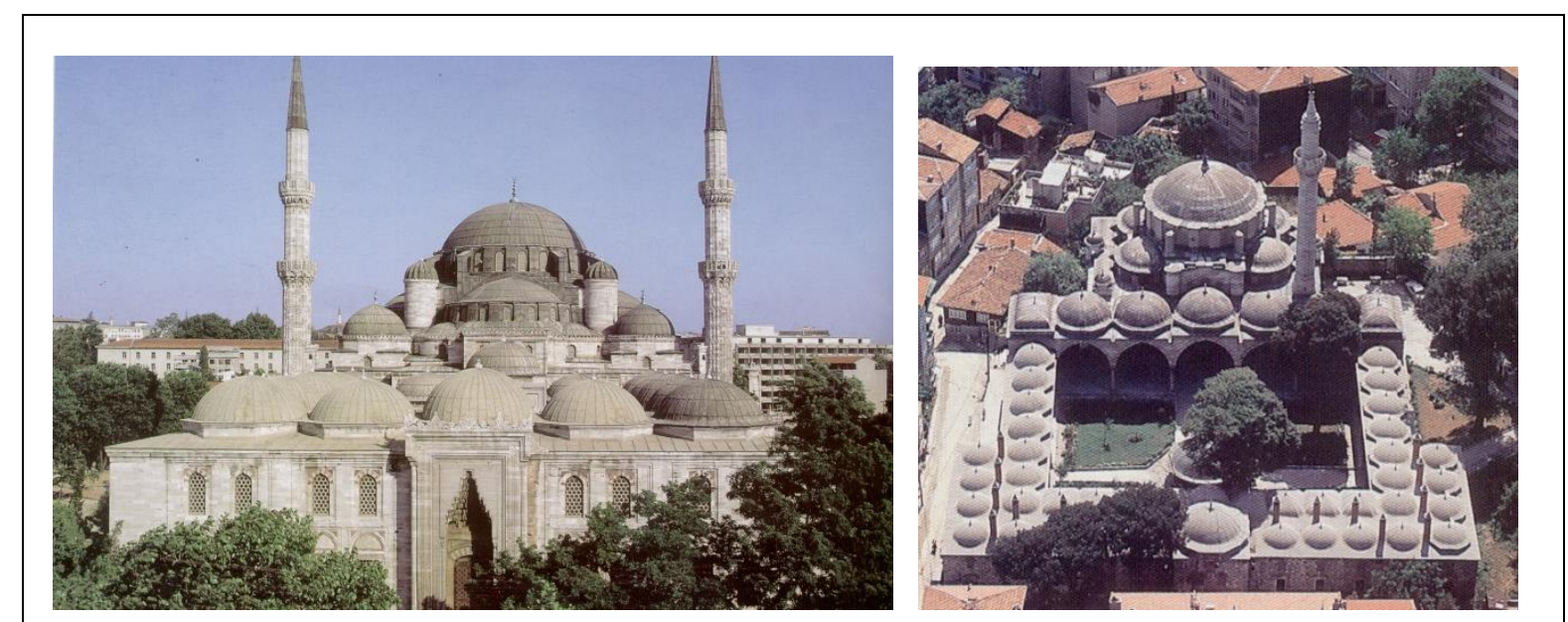

Figure 14. Şehzade Mosque (İstanbul) [Günay, 2002], Ahmet Paşa Mosque (İstanbul) [Günay, 2002]

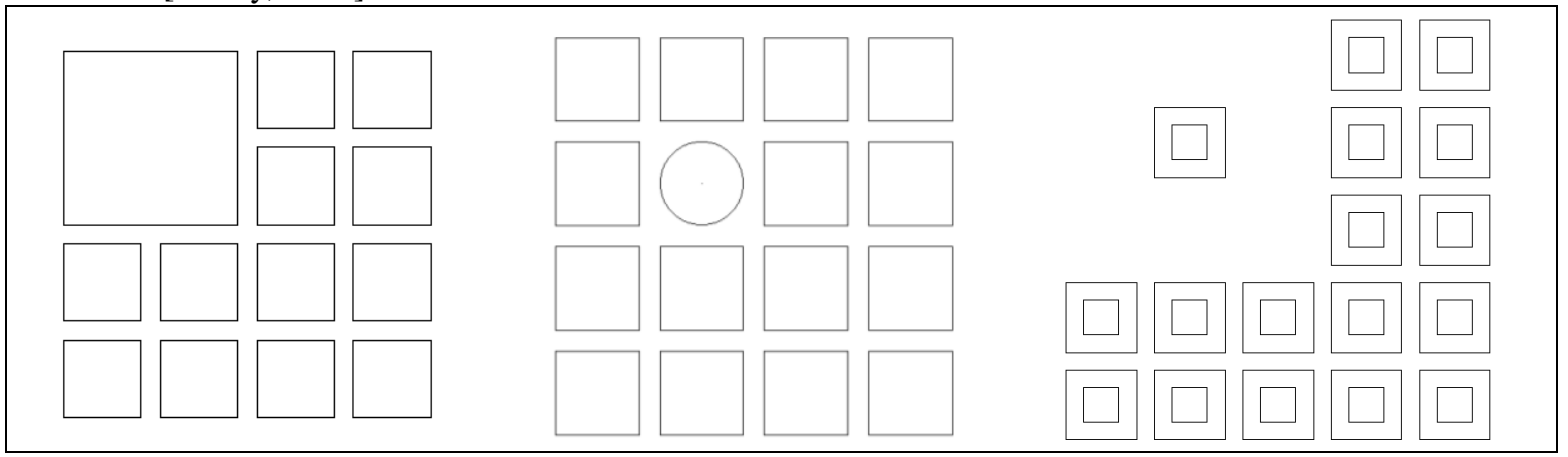

Figure 15. Sovereignty provided by special dimension, sovereignty provided by form difference, dominance with favorable strategic position

3.3. Rhythm (repeat) (repetition): Regular repetition of the elements such as line, form, measure, color, texture in the architectural organizations gives the organizations a rhythmic effect. The rhythm and again, the spatial organization, the organization of the organization is often encountered in frontal arrangements. Beams and columns in the space are repeated to create the necessary openings [Ustaömeroğlu, 1998].
The simplest method for both architects and builders is to repeat the same building elements regularly; Such as empty (may be door or window), full (deaf wall), empty, full. It's like counting one, two, one, two, and it's a rhythm that everybody can grasp. This rhythm, which constitutes a classic example of man's attempt to create order, represents the order and certainty that man has tried to create [Rasmussen, 1994]. 
The tracking of a formal regular, similar items or group of items awakens the sense of repetition over time, called the rhythm. Generally, two factors provide rhythmic effect and detect intensity: the number of repetitive items; Time-space continuity of repetitive items. The rhythmic items in Süleymaniye avlarda are strong. But there is not much intensity. There, the importance of the rhythmic intensity has been given to the proportions and the layout [Kuban, 1993].

More than one use of the same or close to an item brings the rhythmic repetition to the square. The similarity between them serves as a unifying bond, as items, objects, and shapes that are very close to each other are not unrecognizable when they are seen side by side.

Interrelated, consecutive intervals, measures and changes that elements bring to the scene in terms of settling and moving. People find convenience and enjoyment in rhythmic events. The rhythm is a harmony [Odabaş1, 1996].

Divanlığlu rhythm; Line, shape, shape or colors as harmonious or regular repetitions. The items in the random planes are grouped according to the following conditions.

- According to distance and spacing

- According to the visual characteristics they generally share [Divanlıŏlu, 1997; Ching, 2002].

The simplest form of repetition is the linear arrangement of many items. Items should be similar for sequencing as repetitive groups. They should be able to share common lines and diameters so that each item belongs to the same family but each one is unique. It can be collected again in four sections.

- Full Repeat: The items used are the same in size, size, unit, color, value, texture, direction, interval. The arrangement seems monotonous and boring, as there is no change, contrast or contrast between the elements at once. Not interesting [Özek, 1983; Gürer, 1990; Güngör, 1983].

- Repetition: Items, size, shape, color, value, texture are the same but the directions and ranges are different from each other [Divanlıoğlu, 1997].

- Variable Repeat: Generally they are perceived as identical, with small differences between the items used [Divanlığlu, 1997].

- Intermittent Repeat: More than one form, motif, object are used consecutively at certain intervals. Since there are more than one object in the intermittent repetition, monotony and boredom are reduced to some extent (Figures 16, 17, 18, 19), [Divanlıŏlu, 1997; Gürer, 190; Güngör, 1983].

It may not be possible to accommodate the same shape, measure, color, texture in the organization of the places, always repeating objects in the facade arrangements. At the same or similar size, a rhythm can be captured in the way of repeating elements in the form of tissue. For this reason, it is more accurate to determine that the use of rhythm-repetition only without sub-titles and the repetition in the case of multiple use of the design item in regulation, considering that the use of repetition as repetition, repetition, variable repetition, intermittent repetition will not always be possible in architectural applications.

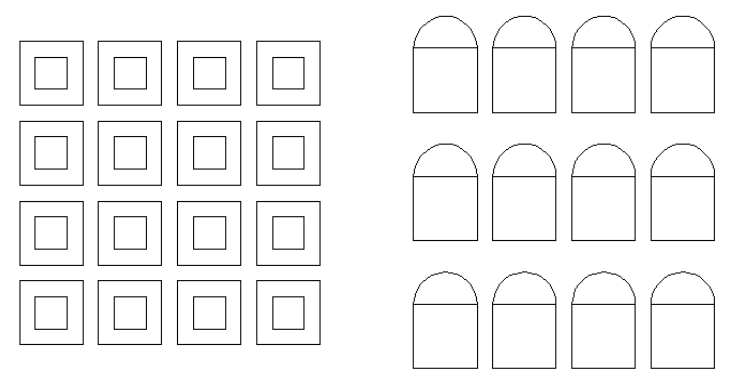

Figure 16. Examples of organizations created with a repeat

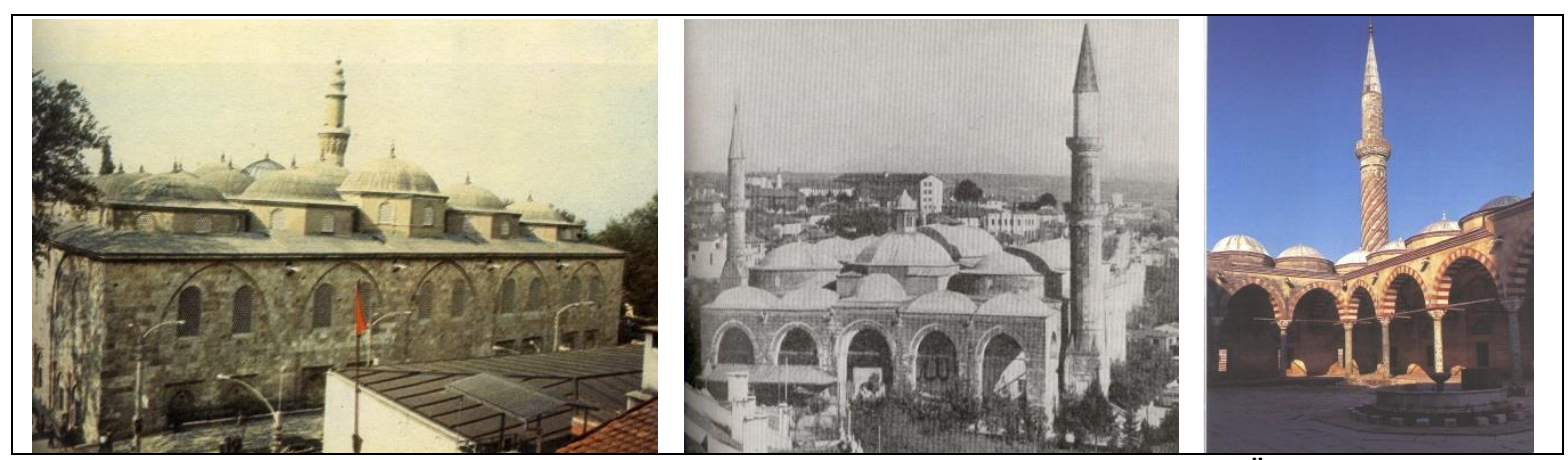

Figure 17. Ulu Mosque (Bursa) [Aslanapa, 1986], Eski Mosque (Edirne) [Kuran, 1964], Üç Şerefeli Mosque (Edirne) [Hattstein, 2000] 


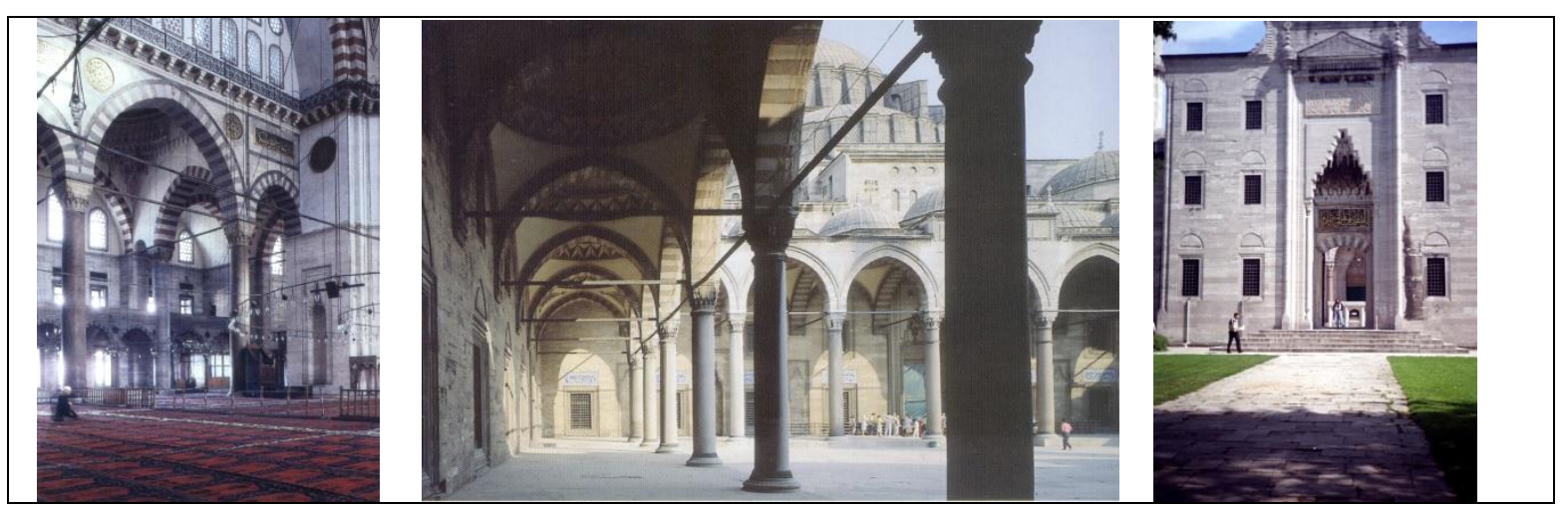

Figure 18. Suleymaniye Mosque interior (Istanbul) [Kuban, 1998], inner court [Günay, 2002], courtyard

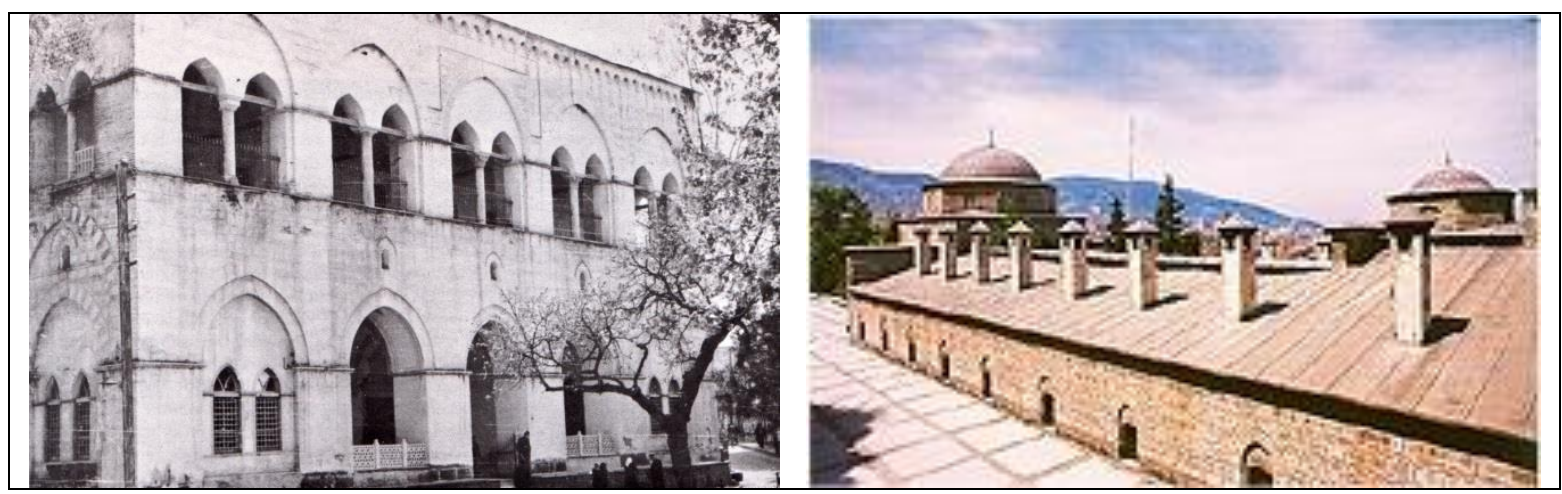

Figure 19. Murat Hüdevandigar Madrasa- Mosque (Bursa) [Aslanapa, 1993], Yıldırım

Madrasa (Bursa) [http://www.bursa.gov.tr/ Bursa. 11-09-2005]

3.4. Balance: In order to be able to create a successful design, the items used are generally felt to be in equilibrium when compared to each other. Integrity of design elements (measure, color, texture, value, spacing, volume, space, shape, direction, ratio, texture, light and shadow) and the use of repetition principles ultimately establishes a balance concept [Divanlıŏ̆lu, 1997].

Forms contrast with each other, and in the case where one of these forms dominates, one can speak of unity and equilibrium. This form of equilibrium is also passed through a balance weighing strainer, depending on the aesthetic values [Gürer, 1990; Güngör, 1983].

The function of a design determines the appropriate balance for the purpose. Symmetrical equilibrium courts, monuments such as banks, cathedrals, parthenons bring a flawless, glorious, dignified and smooth effect for religious tables. The asymmetric balance is; Less peaceful, less evident, but more interesting, and more often used in contemporary art and architecture [Ustaömeroğlu, 1998; Graves, 1951].
The forces and the field that they bring to the field will be reached with equilibrium and equilibrium in spatial power. However, the resulting balance will be perceived as static, static, and lifeless. On the other hand, movements for a living organization are different in terms of optical measures and qualities, ie, in contrast to direction, weight and qualities; But equally strong dynamic balance is achieved in terms of spatial areas [Ustaömeroğlu, 1998].

Balance can be examined in two types as symmetrical (symmetric) and asymmetric (asymmetric).

- Symmetric balance: It is the type of equilibrium balance around a center or an axis. Definite, stable, sedentary, but with little or no maintenance power, monotonous. Şehzade Mosque and Süleymaniye Mosque are examples (Figure 20).

- Asymmetric balance: It is a type of equilibrium in which the elements forming the bill are arranged in a non-symmetrical manner, giving difficult but interesting results. It is the balancing of one or more elements on either side of an axis with dissimilar or contradictory elements (Figure 21) [Divanlığlu, 1997, Ustaömeroğlu, 1998]. 


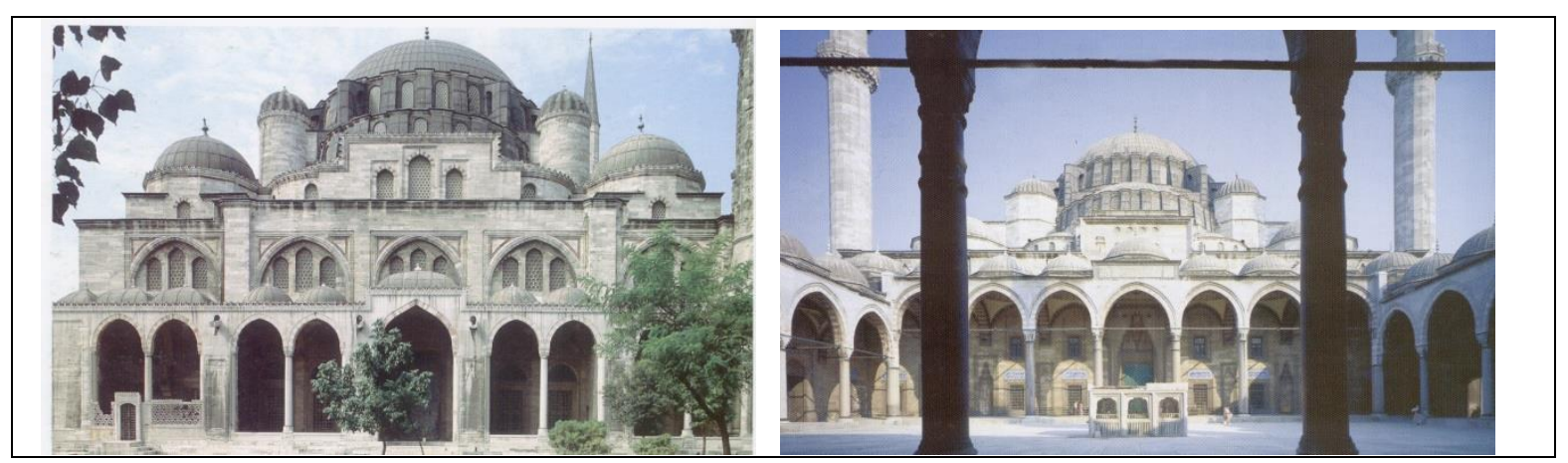

Figure 20. Şehzade Mosque facade (Istanbul) [Günay, 2002], Suleymaniye Mosque inner courtyard (Istanbul)

[Günay, 2002]

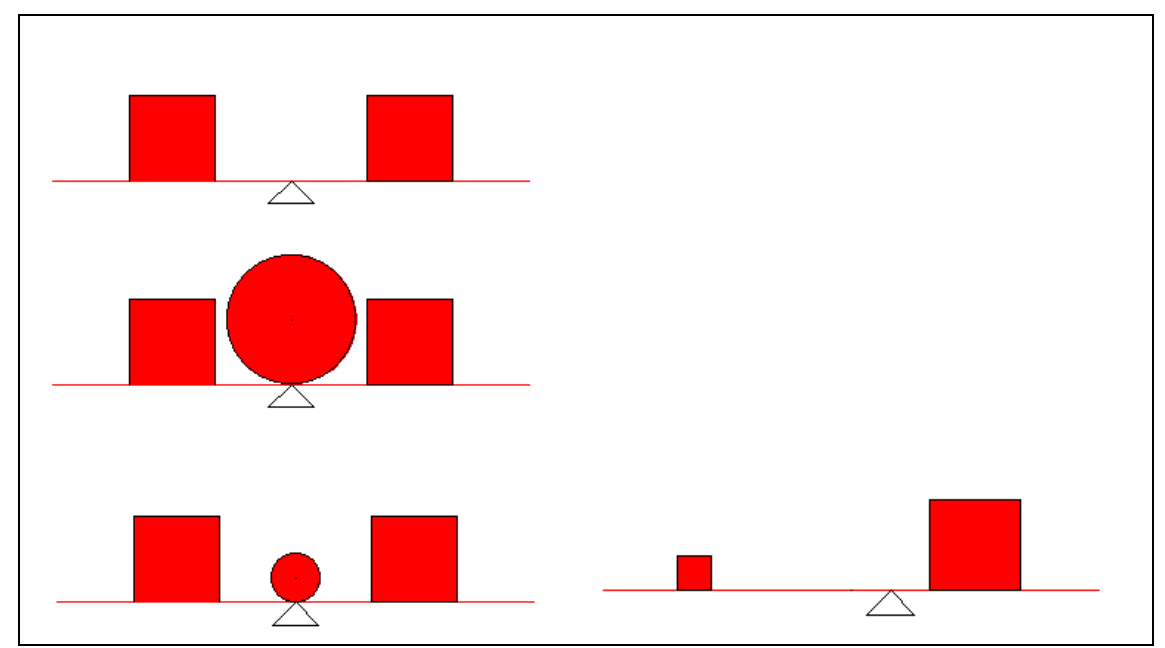

Figure 21. Symmetric balance, asymmetric balance

3.5. Contrast: If there is no similar or common criterion between the groups of objects or entities entering an arrangement in terms of basic design elements, there is a contrast in this arrangement. If constant opposition is applied within an organization, it becomes difficult to establish an interest among the objects and the regulation is perceived at first sight as irregularity, incompatibility. However, if contrast is used at a certain dose in an arrangement, or if many items with contrasts come together in certain quantities, the arrangement will give rise to thoughtful, unexpected effects on the audience, giving the audience excitement and vitality. Contrast is one of the expressions of diversity. When contrast is consciously used within the organization, it creates unity, not unity [Ustaömeroğlu, 1998].

The contrast, used in architectural applications, makes the architectural product look vivid and intriguing. In order to be interesting to a building, your attention needs to be explained by the contrast between verticals and horizons, spaces, sharp and soft forms, volumes and masses [Zevi, 1990].

If there is no size or quality that the two units share, the contrast here corresponds to the irregularity. Contrast is one of the manifestations of diversity. Where there is less variety, monotony begins, which is psychologically brittle. Unequal contradictions, or the diversity of differences between these elements, are also of interest [Gürer, 2004].

As the name suggests, in this primitive design is created by providing contrast between items. It is important because it creates vitality and attracts attention. The size, shape, color, value, texture, direction, and spacing of one or more of the items used to create the design can vibrate to others. An example of this is the measurement contrast in the Sultan Ahmet Mosque dome (Figure 22), [Divanlıŏglu, 1997]. 


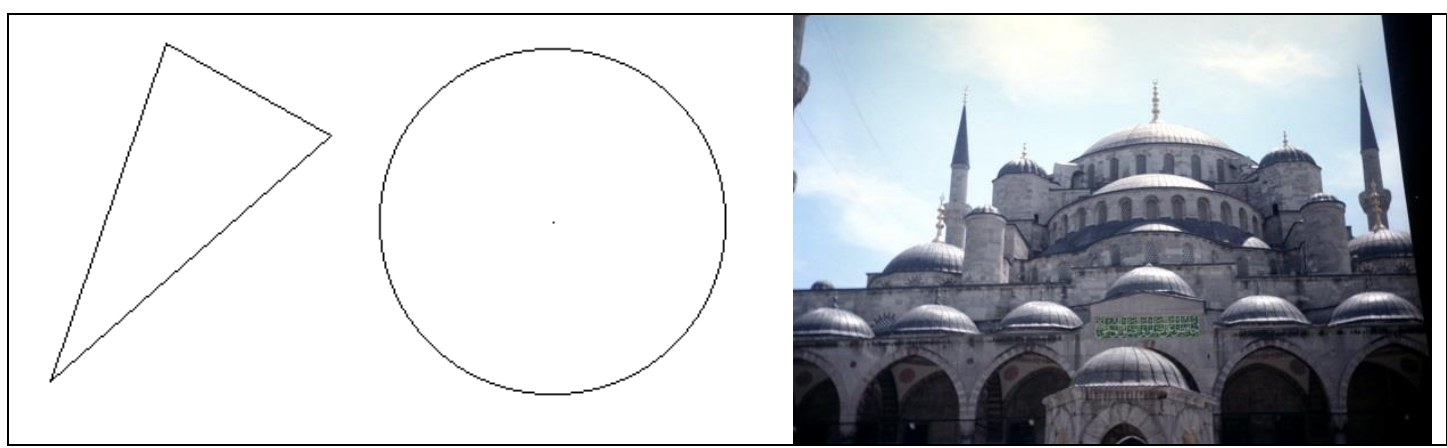

Figure 22. The concept of contrast (contrast) and contrasts in the dimensions of the Sultan Ahmet Mosque dome Coram

3.6.Coram:In the formation of an essay, if there is a degree of gradation among the elements, there may be a coral tree. All design elements, line, direction, measure together; Shape, color variations or color intensity, color grading, value [Gürer, 1990].

If there is an opposition between the two ends, there is the sorting from one end to the other, step by step, from big to small. Again, if tissue coram is to be formed, the two opposing touches must be arranged in such a way that one is arranged in the beginning, the other in the end, and the intervening tissue array does not break the order. The same principles apply to the other cores. In that case, the conditions that have never changed in coram: The contrast between the two extremes is a uniform step between the ends [Güngör, 1983].

The gradual formation that occurs during the application of the Coram in the architecture gives a certain stable image because it is pleasant and can be grasped quickly, it does not force the mind, it is easy to perceive, and the eye looks nice [Ustaömeroğlu, 1998]. The bridge connecting the two opposing corners to each other is called koram. There may be three types of cores, axially, centrally, and environmentally, and one or more of them may coexist in an organization (Figure 23).

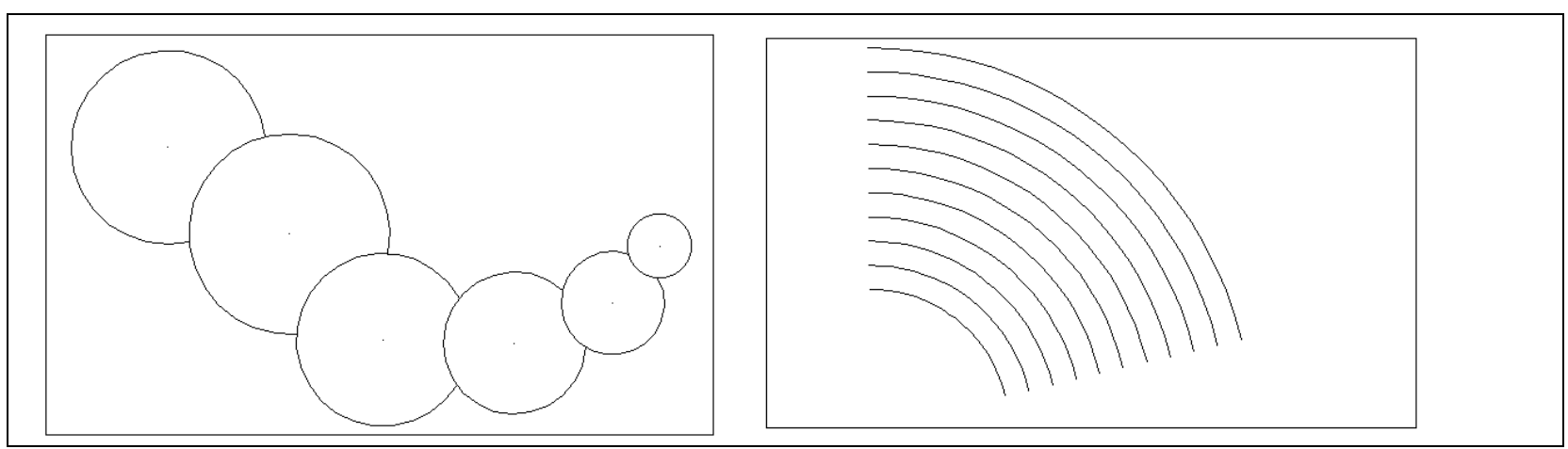

Figure 23. Various examples of coram

- Axial Coram: It is called "coram" which is formed along an axis. The coram can be formed from a straight, curved or broken line (Figure 24).

- Central Ward: One or more wards formed around a center (Figure 24).

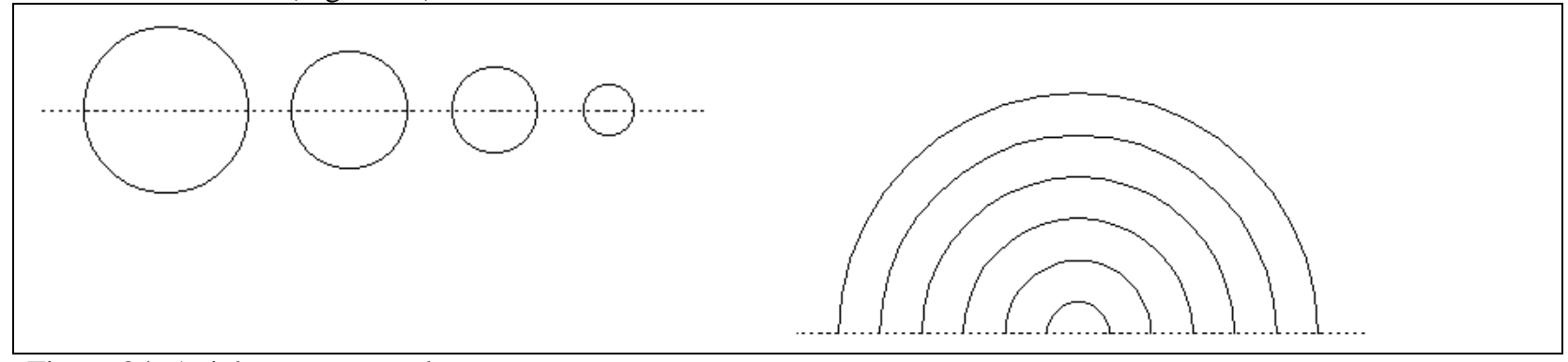

Figure 24. Axial gauge, central gauge 
3.7. Conformity (harmony): The conformity of bodies to common or approximate presence is called [Divanlıoğlu, 1997]. In conformity, the texts do not have to be exactly the same as they were at the same time. The presence of partners or close partners between them increases the possibilities of reconciliation in terms of visual perception within the arrangement and creates a feeling of conformity. Compliance on a single building scale, especially on the facade, windows, doors, facade elements, similar lines, similarities made using similar shapes, close together measurements, only hot or lonely cold colors and color compositions formed with their shades etc. . In the settlement as a whole, the settlement is perceived as appropriate if the buildings adjacent to each other or arranged at certain intervals are similar in terms of the gauges such as the size, shape, texture, color and the surroundings or the size and style of the arrangement. It represents a moderate stability in all respects. Units that are similar to one or more elements such as shape, size, color ... are harmonic. It lies between monotony and contrast. Only harmoniousness in a variety of ways among elements of a design creates monotony, monotony and boredom [Gürer, 1990].

It is not enough to search just for the physical structure of objects. Physical suitability as well as functional suitability, thoughtfulness, etc. (Figures 25, 26), [Güngör, 1983].
- Physical fitness: It is the suitability of an organization to use all, some or all of the basic design elements, such as line, shape, measure, direction, spacing, color,

- Functional conformity: Forms, measures, etc. They do not need to be alike. Objects that have similarity or co-existence with each other, if they are very different from each other, have functional suitability. Cigarette with ashtray, Truler with miter. Like [Ustaömeroğlu, 1998].

- Thought and stylistic appropriateness: In an organization, the coming together of the people is perceived as the product of a thought, a style, if the feeling of unity is felt in the organization of the texts and this whole can spread to the whole of the structure, the idea and the style are appropriate. In this case, there is a sense of unity between both the parts of the structure, as well as between the parts and the whole, according to the same style. On the whole of the organization, the principles of using, processing and coloring the materials that make up each part are arranged in a manner compatible with each other. Just as each designer and artist has his own style, there are styles and styles for the period. By looking at a structure, it can be predicted which rotation it belongs to and which designer's structure it is [Ustaömeroğlu, 1998].
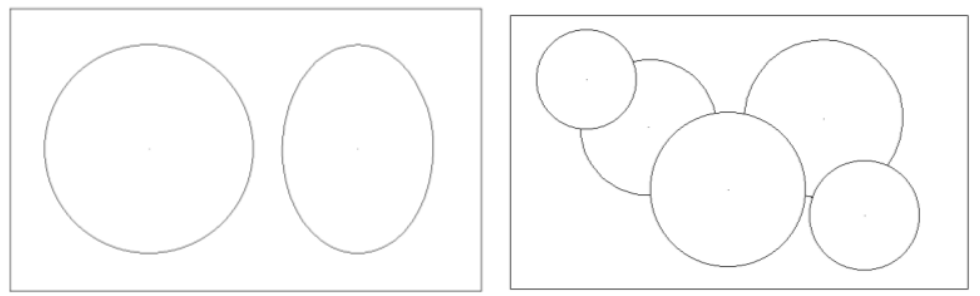

Figure 25. Conformity (harmony)

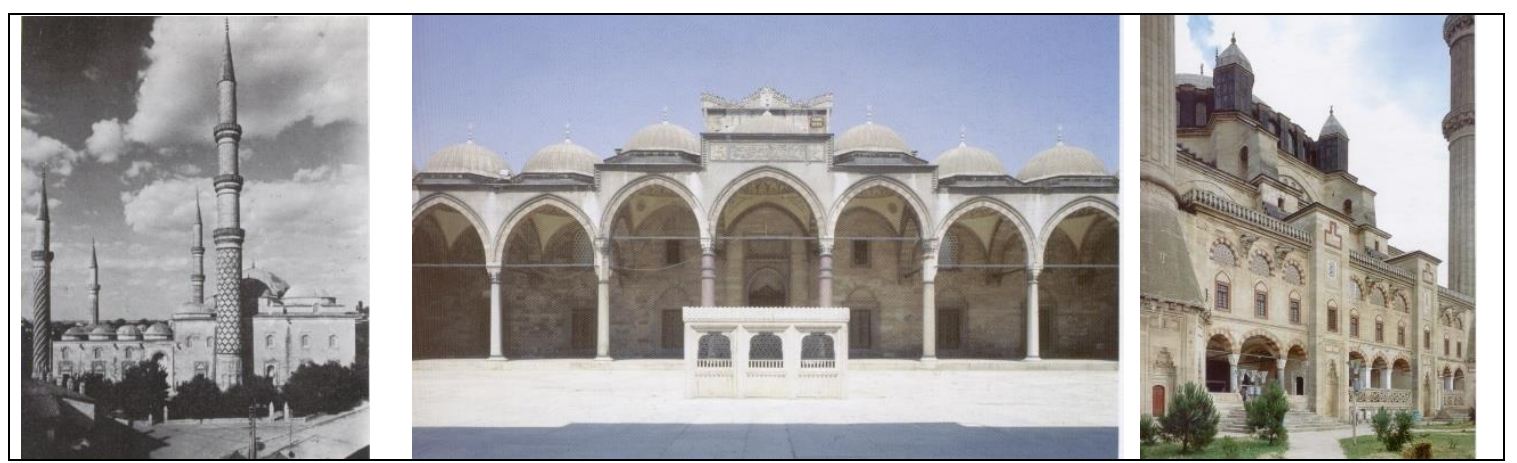

Figure 26. Üç̧ Şerefeli Mosque (Edirne) [Yetkin, 1974], Suleymaniye Mosque inner courtyard (Istanbul) [Günay, 2002], Selimiye (Edirne) [Günay, 2002]

3.8.Increation: A combination of various bodies, spaces, or structures, resulting in a unified whole (unity) [Divanlıoglu, 1997]. The members of the organization can form unity, absolutely repeating or in harmony with each other in form, size, color, texture and so on. They do not depend on their movement. Opposites can also form unity if they are in equilibrium. Towards unity, suitability, opposition and sovereignty show that the path is effective and again plays a reinforcing role in this influence. 
Asymmetric equilibrium and various forms, measures involving union interest is observed; Symmetric equilibrium and repetitive form, units with measures are perceived as more monotonous (Figure 27) [Ustaömeroğlu, 1998].

here are three ways to unite in a veneer. These;

- Convenience way: to reach the Union again, compliance, the principles of koram are used. Unity can be achieved with form and size appropriateness.

- Sovereignty and variability: It is easier to go to the Union. The sovereignty principle is also used. Unity can be achieved with dimensional dominance and shape variability.

- The way of opposition: The opposition principle can also be used to provide a unity of dignity. Unity can be achieved by form appropriateness and dimensional contrast [Divanlıoğlu, 1997].

The main three basic types of unity are mentioned. Static unity, dynamic unity, idea and style association.

- Static unity; Known geometric forms and the associations in the resulting forms. Static unity is passive and static. The static structure is fixed and stationary. Static design is elements or units that are repeated in accordance with a set of units, and refers to a particular form, such as the invariance of a circular arc. Stable and effective. It makes it easy to achieve success in formground expressions. Examples include ornaments and motifs [Uraz, 1993; [Divanlığlu, 1997; Gürer, 1990].

- Dynamic unity; Some transitions and movements are unity that show variability. It is fluent and is an expression. The dynamic unity shows the fluid continuity of a logarithmic spiral starting from the nucleus. For example, a unified urban plan can be shown [Gürer, 1990].

- Idea and style association; All the pieces belonging to one union in an organization are formed by arranging the union according to the main idea. A main idea, such as obtaining a vertical or horizontal effect, or arrangements in accordance with the main idea of the union of all parts involved in the union, with the details of the organization as a whole or with the effort of forming a stylistic union among them [Ustaömeroğlu, 1998].
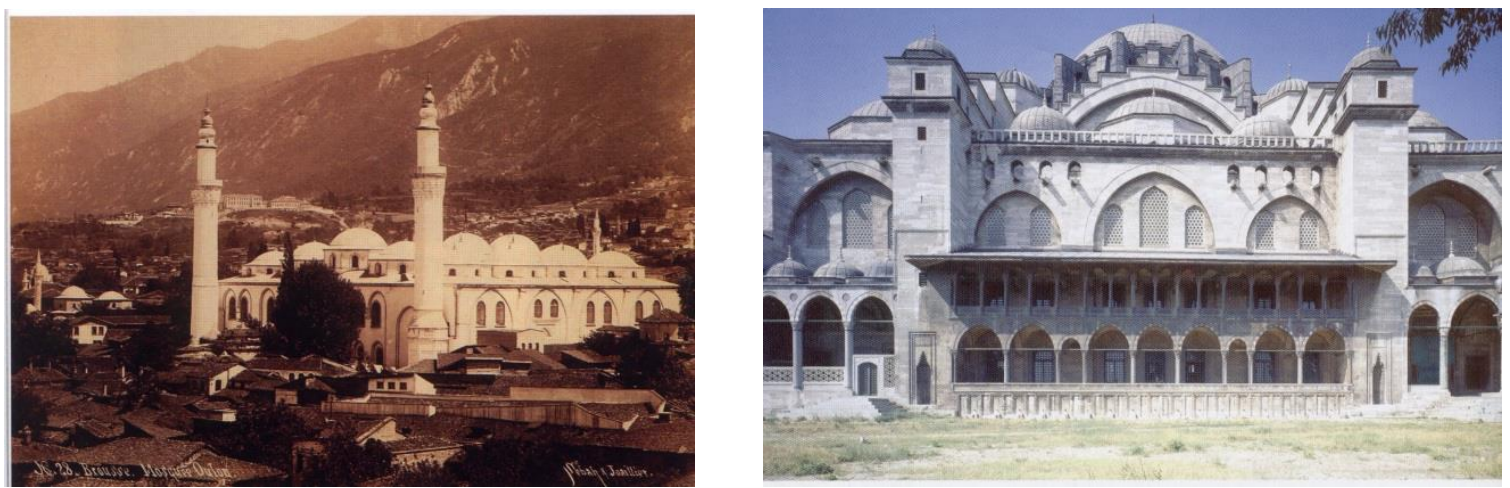

Figure 27. Ulu Mosque (Bursa) [Hattstein, 2000], Süleymaniye Mosque (İstanbul)

[Günay, 2002]

\section{DISCUSSION}

The "Gestalt Theory" explains that all of our perceptions are organized in one whole. A building with a strong formality is perceived as the shape of the other building around it, according to the rear façade (floor) of all natural artificial items. When the linear, superficial, and volumetric effect creates a certain "motion" and strengthens its shape, the aesthetic pleasure begins to delight. This relationship is explained by the isomorphic power between human neurological process and perceived experience. This phenomenon is of great importance in explaining the relationship between artistic and architectural forms of expression and the Gestalt Theory.

According to Arnheim (1971), with the help of Gestalt Theory, it is possible to explain why there are sudden and powerful qualities of perception, with the qualities that are dynamic expression power in aesthetic experience [Graves, 1951; Gürer, 1990].

Accordingly, the human brain works like threedimensional physical forces and directs itself to solid patterns. This cerebral process is parallel to the physical forces that create the good form and stability of tangible beings in the external world.

\section{REFERENCES}

1. Aslanapa, O., Turkish Art for centuries (14th century), State Books, 1977.

2. Aslanapa , O., Turkish Art, Third Edition, Remzi Bookstore, İstanbul, 1993.

3. Aydınl, S., Aesthetic Values in Architecture, First Edition, ITU Faculty of Architecture Printing Studio, İstanbul, 1993. 
4. Ching, F. D. K., Architecture, Form, Place and Order, Lokk S., Yem Publications, İstanbul, 2002.

5. Divanlıoğlu, D. H., Basic Design Elements and Principles, Birsen Yayınevi, İstanbul, 1997.

6. Günay, R., Mimar Sinan ve Eserleri, First Edition, Feed Publication, Istanbul, 2002.

7. Güngör, İ. H., Basic Design, Second Printing, Afa Printing, İstanbul, 1983

8. Graves, M., The Art of Color and Design, McGraw-Hill Book Company, Inc., New York, 1951.

9. Gürer, L., Basic Design, First Edition, ITU Printing, İstanbul, 1990.

10. Gürer, L. ve Gürer, G., Basic design, Birsen Publishing, İstanbul, 2004

11. Hattstein, M. ve Delius, P., Islam Art and Architecture, Könemann, France, 2000

12. Kuban, D., Concepts of Architecture, First Edition, Feed Publications, İstanbul, 1989.

13. Kuban, D., Istanbul Writings on Urban and Architecture, First Edition, Feed Publications, İstanbul, 1998.

14. Kuban, D., Sinan's Art and Selimiye, Second Edition, History Foundation Yurt Publications 65, İstanbul, 1993.

15. Kuran, A., The First Period Ottoman Architecture Mosque, O.D.T.Ü. Faculty of Architecture Publication No: 1, Ankara, 1964.

16. Odabașı, H. A., Graphic Design, Cem Ofset Printing Industry Co.,İstanbul, 1996.
17. Özek, V., Determination of Indicator and Threshold Stage in Architecture, Doctorate Thesis, KT.Ü. Faculty of Architecture and Architecture, Trabzon, 1983.

18. Rasmussen, S., E., Living Architecture, First Edition, Remzi Bookstore, 1994

19. Özbay, Y., Development and Learning Psychology, Empathy Publications, 1999.

20. Tavşan, C., A Research on a Method for Architectural Form Analysis: Application of Modern Architecture Movements in the Last Period Museum Structures, Doctorate Thesis, Institute of Science and Technology, Trabzon, 2000.

21. Ustaömeroğlu, A. A., An Aesthetic Weighted Method Research Using Basic Design Elements and Principles for Architectural Analysis, Ph.D Thesis, Institute of Science and Technology of KTÜ, Trabzon, 1998

22. Uraz, U., Design Thinking Formatting, ITU Faculty of Architecture, Printing Workshop, İstanbul, 1993.

23. Ünsal, B., Turkısh İslamıc Architecture in Seljuk and Ottoman Times 1071-1923, Alec Tirandi, London, 1959.

24. Vitruvius, Ten Books on Architecture, Güven S., Şevki Vanl Architects Foundation, Second Edition, Aralık, 1993

25. Zevi, B., Learning to Learn Mimariyi, Divanlığlu D., Birsen Yayınevi, İstanbul, 1990.

26. Yetkin, S. K., Art in Islamic Countries, Cem Publishing House, İstanbul, 1974

27. http://www.bursa.gov.tr/ Bursa.

11-09-2005 